Çukurova Üniversitesi Mühendislik Mimarlık Fakültesi Dergisi, 30(1), 231-248 ss., Haziran 2015

Çukurova University Journal of the Faculty of Engineering and Architecture, 30(1), pp. 231-248, June 2015

\title{
Al 2024 Alaşımının Çökelme Sertleşmesi İşlemi Koşullarının Şekillendirilebilirliğe Etkisinin İncelenmesi
}

\author{
Murat DÍLMEÇ ${ }^{* 1}$, Mustafa TINKIR ${ }^{1}$, Hüseyin ARIKAN ${ }^{2}$ \\ ${ }^{1}$ N.E.Ü., Mühendislik Mimarlık Fakültesi, Makine Mühendisliği Bölümü, Konya \\ ${ }^{2}$ N.E.Ü., S.A.C. Mühendislik Fakültesi, Makine Mühendisliği Bölümü, Seydişehir, Konya
}

Özet

Geliş tarihi: 05.06.2015 Kabul tarihi: 25.06.2015

$\mathrm{Bu}$ çalışmada, uzay ve havacılık endüstrilerinde sıkça kullanılan Al 2024 sac malzemenin çökelme sertleşmesi işlemi koşullarının mekanik özelliklere, Ericksen İndeksine etkisi ANOVA analiz ve Yapay Sinir Ağı Tabanlı Bulanık Mantık yöntemleriyle incelenmiştir. Ayrıca etkili parametrelerin sac malzemenin Şekillendirme Sınır Eğrisine etkisi de incelenmiştir. Optimum isıl işlem koşullarını belirlemek amacıyla, çözeltiye alma sıcaklığı, firında bekletme, suya verme gecikme süreleri ve isıtma hızının malzemenin mekanik özelliklerine ve Ericksen İndeksine etkisi öncelikle ANOVA analiz yöntemiyle incelenmiş ve elde edilen deneysel sonuçlara göre deney sisteminin yapay sinir ağı tabanlı bulanık mantık modeli oluşturulmuştur. Bu modelleme tekniğinin doğrulanmasında deneysel veriler kullanılmış ve sistem parametrelerinin şekillendirilebilirliğine etkisi üzerinde tahmin kabiliyeti belirlenmiştir. Çözeltiye alma sıcaklığının en efektif parametre olduğu ve solüsyona alma süresi ve suya verme gecikme süresinin ise daha az etkili olduğu belirlenmiştir. Sonuç olarak, $493^{\circ} \mathrm{C}^{\prime}$ de 30 dakika çözeltiye alma ve 2 sn gibi çok kısa bir sürede suya verme koşullarında optimum özelliklerin elde edilebileceği anlaşılmıştır.

Anahtar Kelimeler: Al 2024, Bulanık mantık, Çökelme sertleşmesi Isıl işlemi, Ericksen indeksi

\section{Investigation on Influence of Conditions of Precipitation Hardening Process on the Formability of AA2024 Alloy}

\begin{abstract}
In this study, influence of precipitation hardening process conditions of AA2024 aluminum alloy which is widely used in aerospace and aviation industries on its Ericksen Index and mechanical properties was investigated by using ANOVA analysis and artificial neural network based fuzzy logic methods. Moreover, effects of the effective factors on anisotropy coefficient and Forming Limit Curve were also researched. Firstly, effects of solution temperature, soak time, quenching delay and heating rate on material properties and EI determine the optimal heat treatment conditions and model of artificial neural network based fuzzy logic was constructed according to the obtained results. The experimental data were used for validate this model technique and the predictability of the constructed model on influence of
\end{abstract}

\footnotetext{
* Yazışmaların yapılacağı yazar: Murat DİLMEÇ, N.E.Ü., Mühendislik Mimarlık Fakültesi, Makine Mühendisliği Bölümü, Konya.muratdilmec@konya.edu.tr
} 
delay, respectively. As a result, the optimum values are $493^{\circ}, 30 \mathrm{~min}$. and max. 2 sec. for solution temperature, soak time and quenching delay, respectively.

Keywords: AA 2024, Fuzzy logic, Precipitation hardening, Ericksen index

\section{GíRiş}

Alaşımlı alüminyumlar yüksek mukavemet/ağırlık oranına sahip olması, yüksek korozyon direnci, kolay üretilmesi ve kısmen düşük fiyata sahip olması gibi avantajlarından dolayı [1-3], otomotiv, havacılık ve uzay endüstrilerinde yaygın olarak kullanılmaktadır [4]. Havacılık endüstrisinde tasarımcılar, sürekli bir performans artışı elde etmek için devamlı olarak hafif ve güçlü malzemeler üzerine araştırmalar yapmaktadırlar. Performans artışını sağlamanın ve uçak gövde ağırlığını azaltmanın en verimli yolu malzeme yoğunluğunun azaltılmasıdır. 1920'den beri uçak gövdeleri alaşımlı alüminyumlarından imal edilmektedir. Yüksek mukavemetli 2 XXX ve 7XXX serisi alaşımların havacılık ve otomobil endüstrisindeki kullanımı son yıllarda gittikçe artmaktadır [5]. Alaşımlı alüminyumların uçak gövdesi olarak kullanılmasındaki üstünlüğü Şekil 1'de görülmektedir. Gelecekte uçaklarda alüminyumun rolü kompozit malzemelerin kullanımının artması ile azalacak gibi görünse de, yüksek mukavemetli alaşımlar, sahip olduğu üstün özelliklerden dolayı, önemli bir uçak gövdesi malzemesi olarak kalmaya devam edecektir [1].

2XXX serisinin en önemli alaşımlardan birisi olan, $\% 4,5 \mathrm{Cu}, \% 1,5 \mathrm{Mg}$ ve \%0,6 Mn içeren $\mathrm{Al} 2024$ alaşımı, günümüzde modern havacılık endüstrisinde yüksek mukavemet/ağırlık oranı gerektiren uçak gövdesi, kanadı imalatı için ticari ve savunma uçaklarında sıkça kullanılan bir alaşımdır [2,5]. $\mathrm{Bu}$ alaşım isıl işlemle sertleştirilebilen grubuna girmektedir ve mekanik özellikleri yaşlandırma prosesi ile artırılabilmektedir [3,7]. Isıl işlem ile sertleşen alaşımlar, çökelme sertleşmesi ile mukavemet kazanabilmektedir. Çökelme sertleşmesinin amac1, atomların tane sınırlarına yığıldığı ve homojen olmadığ istenmeyen bir mikroyapıyı, ana faz içerisinde yoğun ve ince çökelmiş parçacıklar dağılımı elde ederek homojen bir mikroyapıya dönüştürmektir. Doymuş katı çözeltilerin çökelmesi devam ettikçe mukavemet artmakta ve nihayet maksimum bir değere ulaşmaktadır. Çökeltiler dislokasyon hareketlerini zorlaştırarak 1sıl işlem görmüş alaşımın dayanımını artırmakta ve uzama kabiliyetini azaltmaktadır. Bir alaşımının çökelme ile sertleşebilmesi için belirli şartların sağlanması gereklidir. Alaşım içerisindeki element veya bileşikler, yüksek sıcaklıklarda oldukça çok, düşük sıcaklıklarda ise pek az çözünebilirliğe sahip olmalıdır [8]. Ayrıca iyi işlenebilirlik, iyi hasar tolerans1, yüksek kırılma tokluğu, kötü korozyon dayanımı, profil çekilebilirliği ve kaynak edilebilirliği bu alaşımın diğer özellikleridir [9].

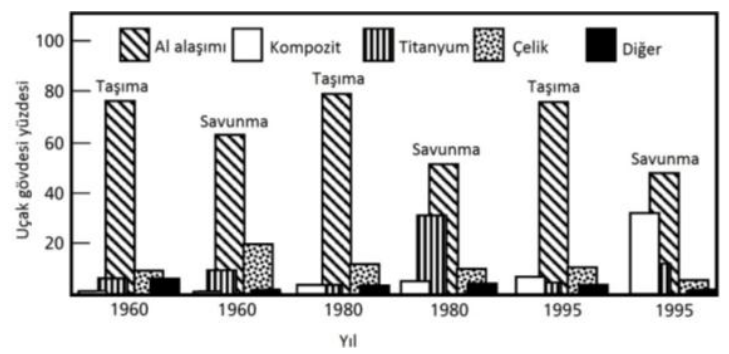

Şekil 1. Uçak gövdesindeki malzeme oranlarının yıllara göre değişimimi [1]

Çökelme sertleşmesi işlemi; solüsyona alma, su verme ve yaşlandırma işlemlerinden oluşmaktadır. Malzeme solvüs sıcaklığının biraz altına kadar ssitılarak tane sinırlarında çökelen 2. fazlar çözündürülüp, homojen tek biçimli $\alpha$ katı solüsyonu elde edilinceye kadar bu sicaklıkta yeterince bekletilir. Solüsyon işleminden sonra atomların potansiyel çekirdeklenme yerlerine difüz etmesi için yeterli zamanı bulmasını engelleyerek istenmeyen 2. fazın oluşmasını önlemek ve solüsyonu aşırı doymuş katı solüsyon haline getirmek için, malzeme firından çıkarıldıktan sonra çok geçmeden hızla daha düşük bir sıcaklığa soğutulur. Bu sayede yapıda fazlaca 2.faz içeren aşırı doymuş ve dengeli olmayan $\alpha$ katı solüsyonu 
oluşturulur. Malzemeyi su vermeden soğumaya terk etmek, katı eriyiklerin tane sınırlarında ve kayma düzlemlerinde çökelmesine ve dolayısıyla şekil değiştirme kabiliyetinin azalmasına sebep olur. $\alpha$ fazı, fazla bakır içeren aşırı doymuş katı eriyiktir ve dengeli bir yapıda değildir [8]. Son olarak aşırı doymuş $\alpha$ içerisindeki dengeli yapıda olmayan 2. fazların çökelmesini sağlayarak homojen ve kararlı bir mikroyapı elde etmek için, malzemenin yaşlandırma işlemine tabi tutulması gerekir. Yaşlandırma işlemi doğal (oda sıcaklığında yaşlandırma) ve yapay olabilmektedir.

Doğal yaşlandırma işlemi, solüsyona alma ve su vermeden sonra malzemenin oda sicaklığında belirli bir süre bekletilerek, katı solüsyon içerisindeki alaşım elementlerinin katı solüsyondan ayrılıp çökelmesiyle malzemenin sertliğinin artması ve özelliklerinin stabil hale gelmesidir [10]. Solüsyona alma ve su verme işleminden sonra malzeme doğal yaşlanırsa $\mathrm{T} 4$, su verme işleminden hemen sonra mekanik özellikleri iyileştirmek için malzeme yeteri derecede soğuk şekillendirilir ve doğal yaşlandırılırsa T3 temperi işaretini alır. T3 ve T4 temperleri ile yüksek çekme/akma mukavemeti oranı, yüksek kırılma tokluğu ve yorulma direnci elde edilir $[11,12]$.

Bazı alaşımlarda oda sıcaklığında birkaç gün bekletme ile yeterince çökelme sağlanarak, çoğu uygulama için yeterli özelliklere sahip kararlı ürünler elde edilebilirken, bazı alaşımlar oda sıcaklığında doğal olarak yaşlandırıldıkları zaman ciddi derecede az kararlı olmaktadırlar. Oda sıcaklığında kararlı olabilen alaşımların bazıları için, özellikle 2XXX serisi, doğal yaşlandırma sonucu T3 ve T4 kullanışlı temperleri elde edilebilmektedir [12].

Al 2024 alaşımının ilk ötektik ergime sıcaklığ (yaklaşık $502^{\circ} \mathrm{C}$ ) literatürde tavsiye edilen maksimum çözelti 1 sıl işlem sıcaklığının sadece birkaç derece üzerindedir. Literatürde firında bu sıcaklıklarda 30 dakika bekletme, su verme ve doğal yaşlandırma sonucu maksimum mukavemet elde edildiği ve mekanik özelliklerin 4-5 gün'de hemen hemen, 7 gün sonunda ise tamamen stabil hale geldiği ve yıllar sonra bile değişiklik göstermediği belirtilmektedir (Şekil 2). Bu durumda malzeme T4 temperi durumuna getirilmiş olmaktadır $[13,14]$.

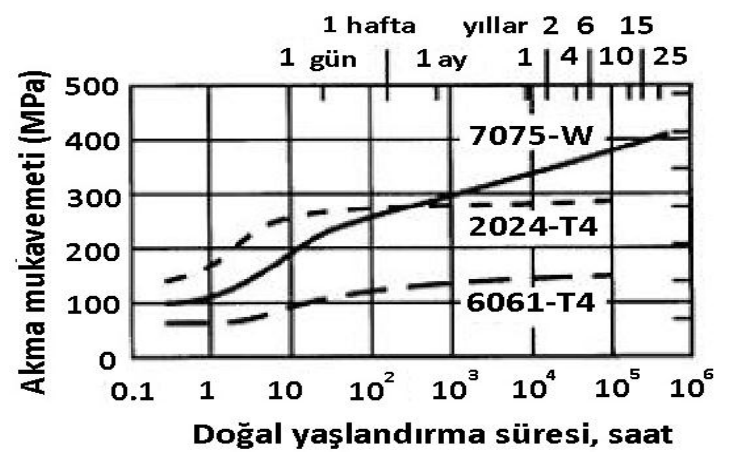

Şekil 2. Farklı alaşımlar için yaşlandırma süresiyle akma mukavemetinin değişimi [12]

$\mathrm{Bu}$ alaşım için maksimum çözeltiye alma sıcaklığının ilk ötektik ergime sıcaklığına çok yakın olmasından dolayı, sıcaklık değeri ve kontrolü çok önemli olmaktadır [2,3]. Alaşım, çözelti 1sıl işlem sıcaklığının üzerinde bir sıcaklığa 1sitılırsa, tane sinırı ergimesi meydana gelir ve malzeme bozulur. Sicaklık çok düşük olursa 2 . fazlar yeterince çözünmez ve dolayısıyla çözelti işlemi tamamlanamaz ve alaşımın mukavemeti beklendiğinden düşük olur. Çözelti isıl işlem süresi bir katı çözelti dengesi oluşturmaya izin vermek için yeterince uzun olmalıdır. Sonuç olarak Al 2024 alaşımı için yüksek mukavemet ve iyi şekillendirilebilirlik elde etmek için çökelme sertleşmesi işleminin optimum parametrelerle dikkatlice yapılması gerekir.

Literatürde 1sıl işlem parametrelerinin çekme testi ile elde edilen mekanik özellikler üzerindeki etkisi incelenmiş olup, bu parametrelerin şekillendirilebilirlik indeksi üzerindeki etkisi incelenmemiştir. Isıl işlem parametrelerinin mekanik özellikler üzerindeki etkiler ise sınırlı parametrelerle incelenmiştir ve yeterli düzeyde değildir. Bu alaşımın 1sıl işlemi çok kritik ve hassas olduğundan uygun isıl işlem koşullarının belirlenmesi ve dikkatlice yapılması gereklidir.

Literatürdeki çalışmalarda Al 2024 alaşımının çökelme sertleşmesi işleminin mekanik özelliklere etkisi ve faktörlerin optimizasyonu üzerine 
çalışmalar sınırlı olup, şekillendirilebilirlik üzerine çalışmaya rastlanmamıştır.

$\mathrm{Bu}$ çalışmada, malzemenin çökelme sertleşmesi işleminde, çözeltiye alma sıcaklığı, firında bekletme, yaşlanma ve suya verme gecikme süreleri ve 1sıtma hızının malzemenin mekanik özelliklerine ve Ericksen İndeksine (EI) etkisi incelenmiştir. Isıl işlem koşullarının etkisi öncelikle ANOVA analiz yöntemiyle incelenmiş ve elde edilen deneysel sonuçlara göre deney sisteminin yapay sinir ağı tabanlı bulanık mantık modeli oluşturularak, test yapılmayan aralıklarda ve farklı koşullarda sistem parametrelerinin şekillendirilebilirliğine etkisi üzerinde tahmin kabiliyeti belirlenmiştir.

\section{MALZEME VE YÖNTEM}

$\mathrm{Bu}$ çalışmada, Al 2024 alaşımının çökelme sertleşmesi işleminde, çözeltiye alma sıcaklığ 1 , firında bekletme, yaşlanma ve suya verme gecikme süreleri ve 1sıtma hızının malzemenin mekanik özelliklerine ve şekillendirilebilirliğine etkisi incelemek amacıyla çekme ve EI testleri için öncelikle Taguçi deney tasarımı yöntemine göre deney tasarımı yapılmıştır. Deney tasarımı Çizelgesine göre çekme ve Ericksen testleri yapılmıştır.

Testlerde kullanılan Al 2024 alaşımının kalınlığ $1 \mathrm{~mm}$ 'dir ve malzemeye ait kimyasal bileşim Çizelge 1'de verilmiştir.

Çizelge 1. Al 2024 alaşımının kimyasal bileşimi (\%ağırlık)

\begin{tabular}{lcccccccc}
\hline $\mathrm{Cu}$ & $\mathrm{Mg}$ & $\mathrm{Mn}$ & $\mathrm{Fe}$ & $\mathrm{Zn}$ & $\mathrm{Si}$ & $\mathrm{Ti}$ & $\mathrm{Cr}$ & $\mathrm{Al}$ \\
\hline 4,44 & 1,29 & 0,6 & 0,13 & 0,093 & 0,068 & 0,027 & 0,002 & 93,35 \\
\hline
\end{tabular}

\subsection{Test Numunelerinin Hazırlanması}

Al 2024 çekme testi numuneleri ASTM E 8M-04'e göre ve Şekillendirme Sınır Eğrisi (ŞSE) numuneleri ise Şekil 3'te görüldüğü gibi ISO 12004-2 standardına göre hazırlanmıştır. Çentik etkisini ortadan kaldırmak amacıyla numunelerin kenarları zımparalanmıştır. Test numuneleri hazırlandiktan sonra numunelere, is1 işlem parametreleri değiştirilerek çeşitli ısıl işlem koşullarında çökelme sertleşmesi işlemi uygulanmıştır.
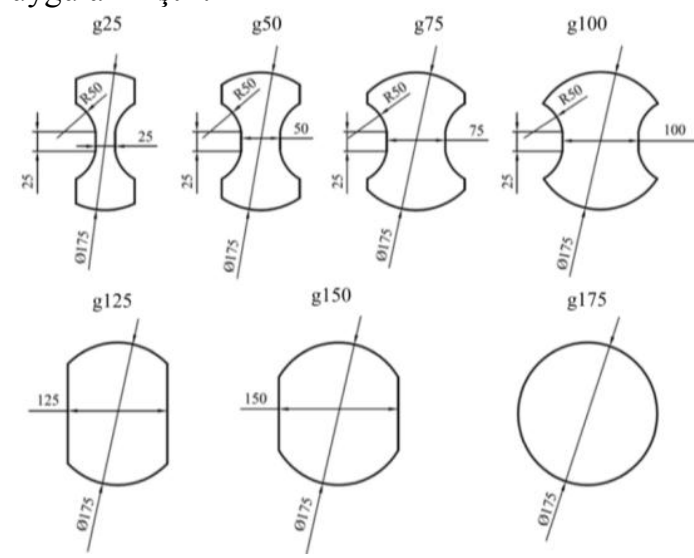

Şekil 3. Nakajima test numune geometrileri

\subsection{Isıl İşlemin Yapılması}

Çökelme sertleşmesi süreci; solüsyona alma, su verme ve yaşlandırma işlemlerinden oluşmaktadır. Al 2024 sac malzemelere isıl işlem parametrelerinin etkisini incelemek amaciyla, numuneler solvüs sıcaklığının oldukça altına, biraz altına ve oldukça üstüne kadar isıtılarak bu sıcaklıklarda bekletilmiştir. Böylece malzemenin tane sınırlarında çökelen 2. fazlar çözündürülüp, homojen tek biçimli $\alpha$ katı solüsyonu elde edilmiştir. Solüsyona alma süresinin etkisini incelemek için numuneler firında 15, 30 ve 50 dakika bekletilmiştir. Solüsyon işleminden sonra numuneler firından çıkarıldıktan sonra 3., 10. ve 30. saniyelerde hızla daha düşük bir sıcaklığa soğutulmuştur. $\mathrm{Bu}$ sayede solüsyon işleminden sonra atomların potansiyel çekirdeklenme yerlerine difüz etmesi için yeterli zamanı bulmasını engelleyerek istenmeyen 2. fazın oluşmasını önlenmiş ve solüsyon aşırı doymuş katı solüsyon haline getirilmiştir ve yapıda fazlaca 2 . faz içeren aşırı doymuş ve dengeli olmayan $\alpha$ katı solüsyonu oluşturulmuştur.

Son olarak aşırı doymuş $\alpha$ içerisindeki dengeli yapıda olmayan 2. fazların çökelmesini sağlayarak homojen ve kararlı bir mikroyapı elde etmek için, numuneler oda sicaklığında 3,7 ve 90 gün 
bekletilerek doğal yaşlandırmaya tabi tutulmuştur. $\mathrm{Bu}$ sayede katı solüsyon içerisindeki alaşım elementlerinin katı solüsyondan ayrılıp çökelmesiyle malzemenin sertliğinin artırılmış ve özellikleri stabil hale gelmiştir.

\subsection{Deney Tasarımı}

Isıl işlem parametre sayısı fazla olduğundan, daha az test yaparak parametrelerin etkisini incelemek amacıyla Taguçi deney tasarımı yöntemine göre test tasarımı yapılmıştır. Çeşitli koşullar için parametrelerin etkisini incelemek amacıyla çekme ve Ericksen testleri hazırlanan deney tasarımı Çizelgesine göre yapılmıştır. Çökelme sertleşmesi işleminde seçilen parametreler ve düzey değerleri Çizelge 2'de verilmiştir.

Al 2024 için etkili çökelme sertleşmesi 1sıl işlem parametrelerini belirlemek amaciyla, matris deneyleri kullanılarak testler yapılmıştır. 4 parametre ve 3 düzey olduğundan L9 matrisi kullanılmıștır. Her bir test üç tekrarlı olarak yapılmıştır. Toplam $81 \times(3$ tekrar $)=243$ test yapılması gerekirken, ortogonal matris sayesinde test sayıs1 $9 \times(3$ tekrar $)=27$ 'ye düşmektedir. Çekme ve Ericksen testleri Çizelge 3'te verilen L9 matrisine göre yapılmıştır.

Ölçülecek karakteristikler, şekillendirilebilirliğin göstergesi olan EI değeri, malzemenin akma, çekme mukavemetleri ve toplam \% uzama değerleri olarak seçilmiştir. L9 reçete Çizelgesi kullanılarak yapılan çekme ve Ericksen testleri sonucunda elde edilen özellikler kullanılarak etkili 1sıl işlem parametreleri ve düzey değerleri belirlenecektir. Problem "en iyi maksimum" problemi olduğundan, maksimum EI, çekme ve akma mukavemetleri ve \% uzama değerlerini sağlayan parametre düzeyleri en uygun düzeyler olarak belirlenmiştir. Sonuçlar varyans analiz (ANOVA) yöntemine göre istatiksel olarak analiz edilmiştir. ANOVA yöntemi kullanılarak, sonuçlara etki eden parametrelerin etki değeri ve en iyi düzeyleri belirlenmiştir. ANOVA yönteminde, her bir kalite karakteristiği için Eşitlik (1) kullanılarak Sinyal-Gürültü $(S / G)$ oranı hesaplanır.
Çizelge 2. Çökelme sertleşmesi işleminde seçilen parametreler ve düzey değerleri

\begin{tabular}{lccc}
\hline Parametreler & \multicolumn{3}{c}{ Düzey Değerleri } \\
\hline A : Solüsyona alma sıcaklığı $\left({ }^{\circ} \mathrm{C}\right)$ & 485 & 493 & 505 \\
B : Solüsyona alma süresi $(\mathrm{dk})$ & 15 & 30 & 45 \\
C : Suya verme gecikme süresi (sn) & 2 & 10 & 30 \\
D : Isınma hızı $\left({ }^{\circ} \mathrm{C} /\right.$ saat $)$ & 250 & 750 & 2500 \\
\hline
\end{tabular}

$\eta=-10 \log \left(\frac{1}{\text { kalite karakteristiğ }}\right)^{2}$

Bir parametre düzeyinin etkisi, parametrenin o düzeyi ile ilişkili sonuçların ortalaması ile elde edilir. Örneğin, $A$ parametre düzeyinin etkisi $\left(m_{A 1}\right)$ Eşitlik (2) kullanılarak bulunur.

$m_{A 1}=\frac{1}{3}\left(\eta_{1}+\eta_{2}+\eta_{3}\right)$

Çizelge 3. L9 ortogonal matris

\begin{tabular}{ccccc}
\hline Test & $\begin{array}{c}\text { Solüsyona } \\
\text { alma } \\
\text { No } \\
\text { sicaklığı } \\
\left({ }^{\circ} \mathbf{C}\right)\end{array}$ & $\begin{array}{c}\text { Solüsyona } \\
\text { alma } \\
\text { süresi } \\
(\mathbf{d k})\end{array}$ & $\begin{array}{c}\text { Suya } \\
\text { verme } \\
\text { gecikme } \\
\text { süresi } \\
(\mathbf{s n})\end{array}$ & $\begin{array}{c}\text { Isınma } \\
\text { hızı }\left({ }^{\circ} \mathbf{C} /\right. \\
\text { saat }) \\
\text { D }\end{array}$ \\
\hline $\mathbf{A}$ & 485 & 2 & 15 & 250 \\
\hline $\mathbf{C}$ & 485 & 10 & 30 & 750 \\
\hline $\mathbf{3}$ & 485 & 30 & 45 & 2500 \\
$\mathbf{4}$ & 493 & 2 & 30 & 2500 \\
$\mathbf{5}$ & 493 & 10 & 45 & 250 \\
$\mathbf{6}$ & 493 & 30 & 15 & 750 \\
$\mathbf{7}$ & 505 & 2 & 45 & 750 \\
$\mathbf{8}$ & 505 & 10 & 15 & 2500 \\
$\mathbf{9}$ & 505 & 30 & 30 & 250 \\
\hline
\end{tabular}

A parametresinin karelerinin toplamı Eşitlik (3) kullanılarak hesaplanır.

$=3\left(\left(m_{A 1}-m\right)^{2}+\left(m_{A 2}-m\right)^{2}+\left(m_{A 3}-m\right)^{2}\right)$

Burada $m, \quad$ 'nın ortalamasıdır. Bu durumda karelerin toplamı her bir parametrenin serbestlik derecesine bölünür ve parametrelerin karelerinin ortalamas1 belirlenir. Serbestlik derecesi düzey sayısının bir eksiğine eşittir. Varyasyon oranı, her bir parametrenin karelerinin ortalamasinın hataların karelerinin ortalamasına bölünmesi ile 
elde edilir. Katkı oranı, her bir parametrenin karelerinin toplamının toplam karelerin toplamına oranı olarak tanımlanır. Sonuçta, her bir parametrenin etkisi katkı oranı kullanılarak bulunur.

\section{4. Çekme Testlerinin Yapılması}

Al 2024 sac malzemelerin mekanik özelliklerinin belirlenmesi amaciyla ASTM E 8M-04'e göre hazırlanan numunelere çekme testleri yapılarak malzemenin bazı mekanik özellikleri elde edilmiştir. Testler Shimadzu AG-IS marka çekme cihazında gerçekleştirilmiştir.

Çekme testinden önce, numunelerin ilk ölçü boyları hassas kumpas ve mikrometrelerle ölçülmüştür. Sonra numunelerin üzerine 50 mm'lik bir ilk ölçü boyu işaretlenmiş ve tutma kısımlarından çekme cihazının çenelerine bağlanarak kopuncaya kadar $25 \mathrm{~mm} / \mathrm{dk}$ hızda çekilmiştir. Çekme sırasında ölçü boyunda meydana gelen değişim video ekstansiyometre ile $\pm 0,003 \mathrm{~mm}$ doğrulukla ölçülürken, yük değeri de yük hücresi yardımıyla ölçülerek veriler bilgisayara aktarılmıştır. Çekme testleri üç tekrarlı olarak yapılmıştır.

Al 2024-T4 alaşımı gevrek bir yapıya sahip olduğundan, akma noktası uzaması açık olarak görülemediği için, 0,002 birim şekil değiştirme (BŞD) değerinden akma eğrisinin elastik kısmına çizilen paralelin akma eğrisini kestiği noktadaki gerilme değeri akma mukavemeti olarak alınmıştır. Maksimum mukavemet değeri ve toplam \% uzama değeri ise elde edilen verilerden kolaylıkla tespit edilmiştir. Malzemeye ait akma, çekme mukavemetleri ve toplam uzama değerleri tüm koşullardaki testler için belirlenmiştir.

\section{5. Şekillendirme Sınır Eğrisinin ve Ericksen İndeksinin Elde Edilmesi}

$\mathrm{Bu}$ çalışmada tüm 1sıl işlem koşulları için şekillendirilebilirliği göstergesi olan EI'lar belirlenirken, sadece en etkili parametrelerin değişimi için sac malzemenin hangi sınırlara kadar şekil değiştirebileceği bilgisini veren en önemli araçlardan biri olan Şekillendirme Sınır Eğrisi
(SSE) ISO 12004-2 standard1 kullanılarak elde edilmiştir.

ŞSE'ler, Nakajima (gerdirme) veya Marciniak (derin çekme) deneylerinden elde edilebilmektedir [15]. Nakajima deneyinde gerçek şekillendirme proseslerinde oluşan eğilme gerilmeleri de meydana gelmektedir. Gerçek şekillendirme proseslerine yakın olmasından ve geniş bir aralıkta BŞD yolu elde edilebilmesinden dolayı, Nakajima deneyi daha yaygın olarak kullanılmaktadır [16]. Bu nedenle, bu çalışmada da Nakajima testi kullanılmıştır. Kalıp seti bir adet süzdürme çubuklu baskı plakası, bir adet alt kalıp ve bir adet $100 \mathrm{~mm}$ çapında yarı küresel stampadan oluşmaktadır. Nakajima testinin yapılışı; numunelerin kesilerek 1 sıl işlem uygulanması, numunelerin yüzeyine grid yapıların oluşturulması ve şekillendirme işlemlerinden oluşmaktadır. İlk olarak Şekil 3'te görülen numunelere 1 sıl işlem uygulandiktan sonra, bir yüzeyleri şekillendirme işleminden önce, serigrafi yöntemiyle $2,5 \times 2,5 \mathrm{~mm}$ boyutunda kare gridler oluşturulmuştur (Şekil 4). Sonra numunelerin gridsiz yüzeyi ve stampa yüzeyi oldukça düşük sürtünme katsayısına sahip parafinle yağlandıktan sonra, Şekil 5'te görülen $100 \mathrm{~mm}$ çaplı yarı küresel bir stampaya ve süzdürme çubuğuna sahip kalıp seti kullanılarak boyunlaşma veya yırtılma başlangıcına kadar şekillendirilmiştir. Süzdürme çubuğuna sahip baskı plakası ile bastırılmasının amacı numunenin kalıp içerisine akışı engellemektir.

Testler standartta verilen en düşük hız değeri olan $60 \mathrm{~mm} / \mathrm{dk}$ hızda ve numunenin kalıp içerisine akışını önlemek amacıyla $\sim 150 \mathrm{kN}$ baskı plakası kuvveti ile yapılmıştır. Presin baskı plakası kuvveti, stampa hizı ve konumu hassas olarak kontrol edilebilmektedir. Ayrıca stampada belirli bir kuvvet düşüşü olduğu zaman, stampay1 geri çekerek şekillendirme işlemini sonlandıracak bir program yazılmıștır. Şekillendirme işlemi $0.5 \mathrm{~kg}$ l1k bir kuvvet düşüşünde, yani hasar oluşur oluşmaz, sonlandırılabilmiştir.

Al 2024-T4 gevrek bir yapıya sahip olduğundan tüm numunelerde boyunlaşma başlangıcı elde edilememiş ve tüm numuneler yırtılmıştır. 


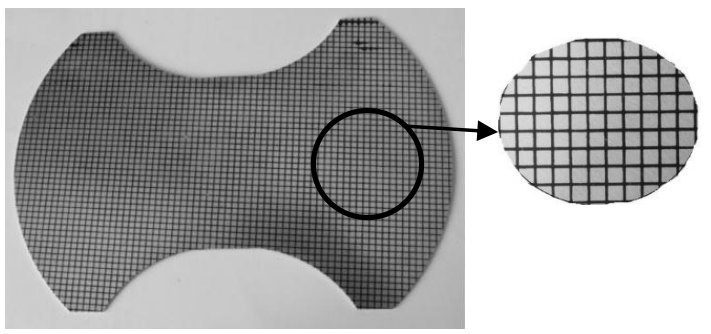

Şekil 4. Yüzeyi gridlenen örnek bir Nakajima numunesi



Şekil 5. Nakajima testi kalıp seti [17]

$\mathrm{Bu}$ çalışmada numune üzerindeki BŞD dağılımları bilgisayarlı grid analizi yöntemiyle elde edilmiştir. $\mathrm{Bu}$ yöntemin uygulanışı Dilmeç (2012) [18] çalışmasında anlatılmıştır. Sınır birim şekil değiştirmeleri (sınır BŞD) ISO standardına göre belirlemek için, Microsoft Excell yazılımında yazar tarafindan daha önce yazılan bir program kullanılmıştır. Grid analiz programında BŞD dağılımı belirlenen numuneler üzerinde standartta belirtildiği gibi çizilen kesitler boyunca elde edilen majör ve minör BŞD değerleri geliştirilen programda ISO 12004-2 standardına göre değerlendirilerek sınır BŞD'ler belirlenmiştir. Yazılan bu programın doğruluğu Dilmec ve ark (2013) [19] çalışmalarında ortaya konulmuştur. EI'ler ise $175 \mathrm{~mm}$ çapındaki hasarlanmış numunelerin kubbe yükseklikleri kumpas ve yükseklik kumpasıyla ölçülerek elde edilmiştir.

\subsection{Anizotropi Katsayısının Elde Edilmesi}

En etkili parametre için malzemelerin normal anizotropi değerleri ASTM E-517 standardına göre belirlenmiştir. Testlerde diğer parametreler için optimum değerler kullanılmıştır. Haddeleme doğrultusu ile $0^{\circ}, 45^{\circ}$ ve $90^{\circ}$ açılarda kesilen dikdörtgen numunelere 1sıl işlem uygulandıktan sonra, numunelerin orta k1sminda $50 \mathrm{~mm}$ 'lik boy ve tüm genişlik boyunca serigrafi yöntemiyle, $0,2 \mathrm{~mm}$ çizgi kalınlığına sahip $2.5 \times 2.5 \mathrm{~mm}$ kare şeklinde gridler oluşturulmuştur. Daha sonra numuneler Shimadzu AG-IS marka çekme cihazında $25 \mathrm{~mm} / \mathrm{dk}$ hızda \%10 BŞD değerine kadar çekilmiştir. Deneyler üç tekrar ile yapılmıştır. Anizotropi katsayılarını belirlemek için grid analiziyle ölçme yapan ASAME 2D 4.1 görüntü işleme yazılımı kullanılmıştır.

Grid analiziyle ölçmede, her bir numune yüzeyindeki grid yapısının referans almak için çekme işleminden önce ve çekme sırasında belirli uzama değerlerinde, 12 MP çözünürlükteki Canon 450D marka profesyonel bir SLR kamera ile fotoğrafları çekilmiştir (Şekil 6). Birçok malzeme için maksimum çekme noktasına kadar normal anizotropi değeri genellikle sabit kalmaktadır. Bu nedenle genellikle $\% 10$ uzamadaki $r$ değeri alınmaktadır. Farklı uzama değerlerinde farklı anizotropi değerleri veren malzemeler için, $r$ değeri ile birlikte hangi uzama değeri için elde edildiği de belirtilmelidir.

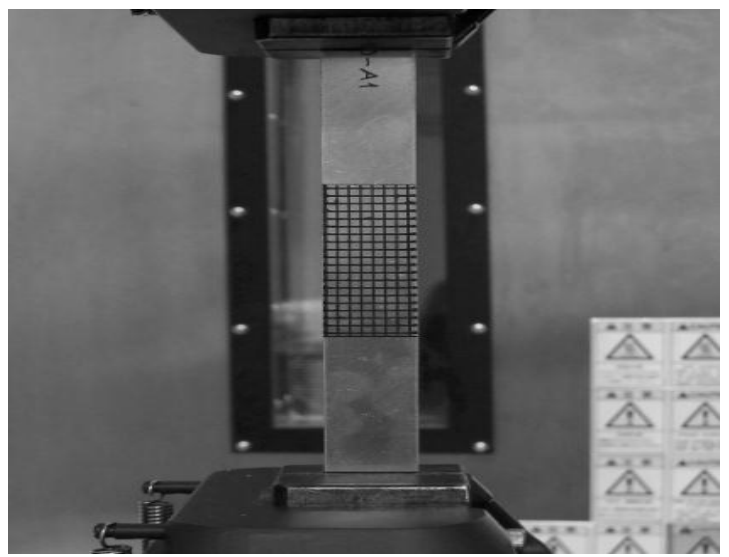

Şekil 6. Anizotropi değerinin belirlenmesi için çekilen örnek bir fotoğraf

Grid analizi yapan görüntü işleme yazılımıyla fotoğraflar üzerinden $50 \mathrm{~mm}$ 'lik ölçü boyunca $\% 10$ uzama sonucunda gridlerde meydana gelen $\varepsilon_{l}$ ve $\varepsilon_{w} \mathrm{BSSD}$ değerleri belirlenmiştir. Anizotropi değeri, numuneler üzerinde değerler kullanılarak hesaplanmıştır. Elde edilen bu veriler kullanılarak 
$\varepsilon_{l}+\varepsilon_{w}+\varepsilon_{t}=0$ hacim sabitliği kuralından, her bir grid için kalınlık doğrultusundaki BŞD miktarları hesaplanarak anizotropi katsayıları

$r=\frac{\varepsilon_{w}}{\varepsilon_{t}}$

eşitliğinden elde edilmiştir.

\subsection{Yapay Sinir Ăğı Tabanlı Bulanık Mantık Modellemesi}

Çalışmanın amacına uygun olarak deneysel sonuçların tahmin edileceği bir yapay sinir ağı tabanlı bulanık mantık modeli oluşturulmuştur. $\mathrm{Bu}$ modelde 4 giriş 4 çıkış parametresi bulunmaktadır. Oluşturulan modelin yapısı Şekil 7'de verilmiştir. Buna göre solüsyona alma sıcaklığı, solüsyona alma süresi, suya verme gecikme süresi ve isınma hızı giriş parametreleri olarak alınmıştır. Deneysel elde edilen EI, akma mukavemeti, çekme mukavemeti ve toplam uzama çıkış parametreleri olarak ele alınmıştır. Şekil 8'de girişler için oluşturulan üyelik fonksiyonları verilmiştir. Üyelik fonksiyonları olarak simülasyonlarda en uygun tahmin sonuçlarını veren gauss tipi üyelik fonksiyonları kullanılmıştır. Çıkış değerleri ise modelin belirlemiş olduğu sabit değerlerdir. Bu amaçla 256 adet kuraldan oluşan kural tabanı oluşturulmuştur.

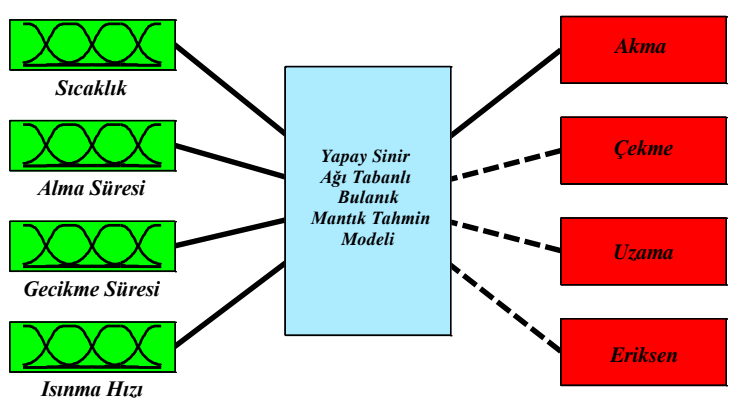

Şekil 7. Yapay sinir ağı tabanlı bulanık mantık modelinin yapis1

Modelin oluşturulmasında MATLAB/Anfis yazılımı, simülasyonlarda ise MATLAB/Simulink yazılımı kullanılmıştır. Şekil 9'da oluşturulan kural tabanı ve yapay sinir ağının yapısı verilmiștir. Cizelge 3'e göre 9 adet test yapılmıștır. Bu sonuçlardan 1., 4., 5., 6., 8., ve 9. testlere ait sonuçlar ağ yapısı içine test datası olarak kullanılmıştır. Diğer sonuçlar ise eğitim datası olarak kullanılmıştır.
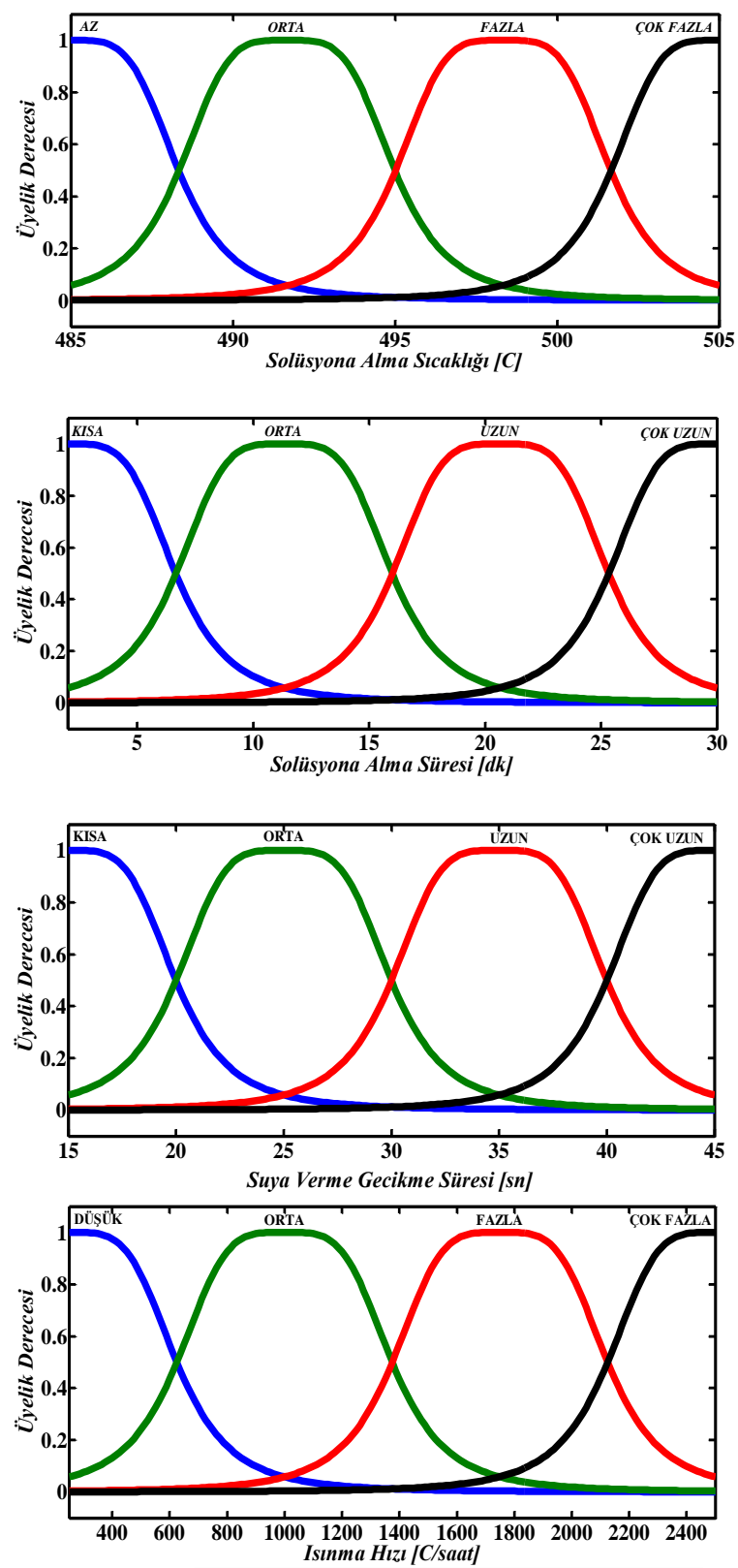

Şekil 8. Girişler için oluşturulan üyelik fonksiyonları 


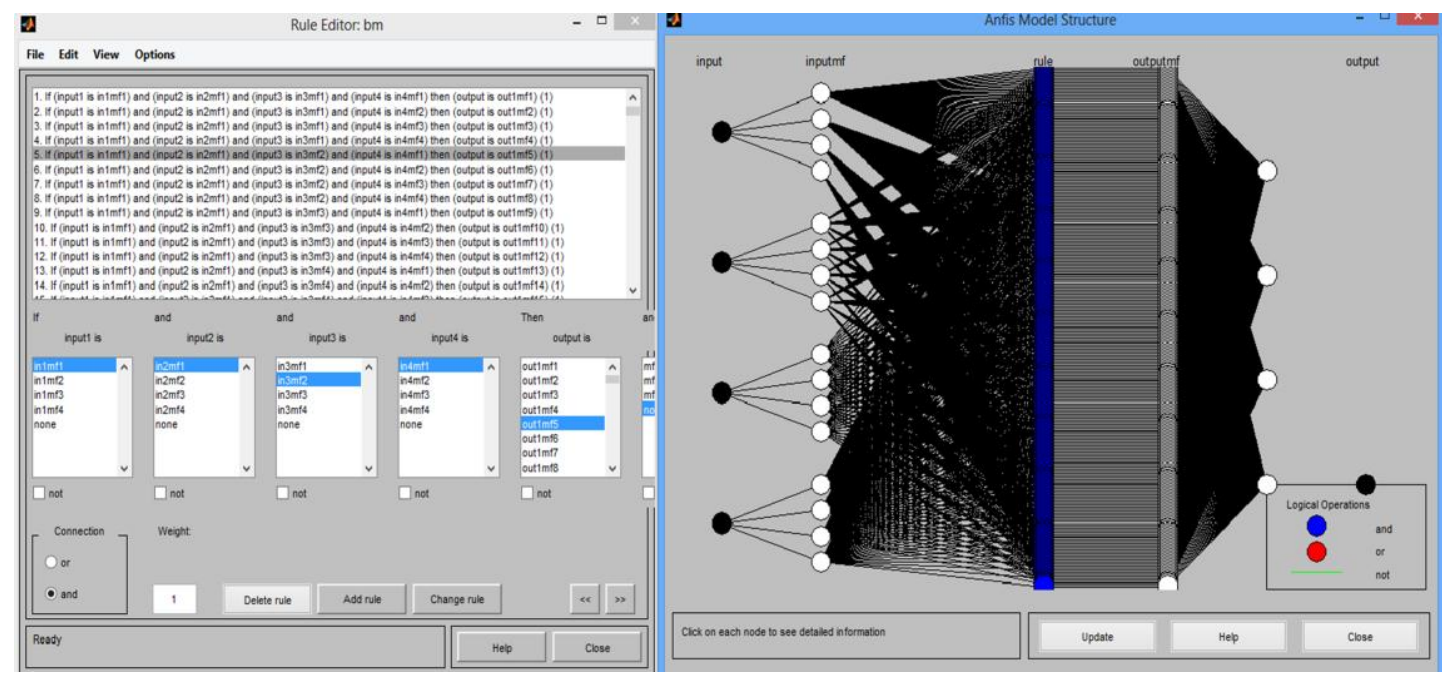

Şekil 9. Kural tabanı ve ağ yapısı

\section{BULGULAR VE TARTIŞMA}

Isıl işlem koşullarının EI, akma mukavemeti ve \% uzama üzerindeki etkisinin incelenmesi için, yapılan Ericksen ve çekme testleri doğal yaşlandırmanın aynı gününde yapılmıştır. Yapılan incelemeler sonunda, çeşitli ısıl işlem koşulları için doğal yaşlandırmanın farklı günlerinde elde edilen Al 2024 malzemeye ait akma eğrilerinin, doğal yaşlandırmanın 5. gününden sonra hemen hemen stabil hale geldiği belirlenmiştir (Şekil 10). Bu nedenle tüm testler doğal yaşlandırmanın 7 . gününde gerçekleştirilmiştir.

L9 tasarım matrisi kullanılarak yapılan 1sıl işlem koşullarındaki numunelere yapılan çekme ve Ericksen testleri sonucunda elde edilen EI, akma, çekme ve toplam \% uzama değerleri Çizelge 4'te verilmiştir [20]. Deney tasarımı Çizelgesindeki 1sıl işlem koşullarındaki numunelerin testlerinden elde edilen EI, akma mukavemeti, toplam \% uzama değerleri için ANOVA Çizelgeleri sırasıyla Çizelge 5, Çizelge 6 ve Çizelge 7'de verilmiştir [20].

Parametre düzeylerinin elde edilen EI, akma mukavemeti ve toplam \% uzama değerlerine etkileri sırasıyla Şekil 11, Şekil 12 ve Şekil 13'te verilmişstir.
Parametrelerin en uygun düzeylerine her bir parametrenin etki grafiği ile de karar verilebilir. Şekiller incelendiğinde, çözeltiye alma sıcaklığının en efektif parametre olduğunu ve en iyi özellikler için en uygun sicaklığın $493^{\circ} \mathrm{C}$ olduğunu görülmektedir. Daha düşük ve yüksek sıcaklıklar için EI, akma mukavemeti, toplam \% uzama değerleri önemli ölçüde azaldığı gözlenmiştir. Daha sonraki etkili parametre ise solüsyona alma süresi ve suya verme gecikme süresidir. Bu parametrelerin etkileri birbirine oldukça yakın elde edilmiştir. Çözeltiye alma süresinin etkisi, suya verme gecikme süresinin etkisinden biraz daha fazla olduğu söylenebilir. En iyi özellikleri sağlayacak çözeltiye alma süresinin en uygun değeri 30 dakika olarak tespit edilmiştir.

Malzeme bu sıcaklıktan daha düşük ve daha yüksek sürelerde firında bekletildiği zaman, EI, akma mukavemeti ve toplam \% uzama değerlerinin azaldığı görülmektedir. Suya verme gecikme süresi arttıkça, EI, akma mukavemeti ve toplam \% uzama değerleri önemli derecede azalmaktadır. Bu durumda Al 2024 malzemenin, en iyi özellikleri elde etmek amacıyla, çözeltiye alma işlemi sonunda en fazla 2 sn gibi çok kısa bir sürede suya verilmesinin uygun olacağı sonucuna varılmıştır. Şekillerden görüldüğü gibi ısınma hızının malzemenin özelliklerini önemli oranda etkisinin olmadığı söylenebilir. 


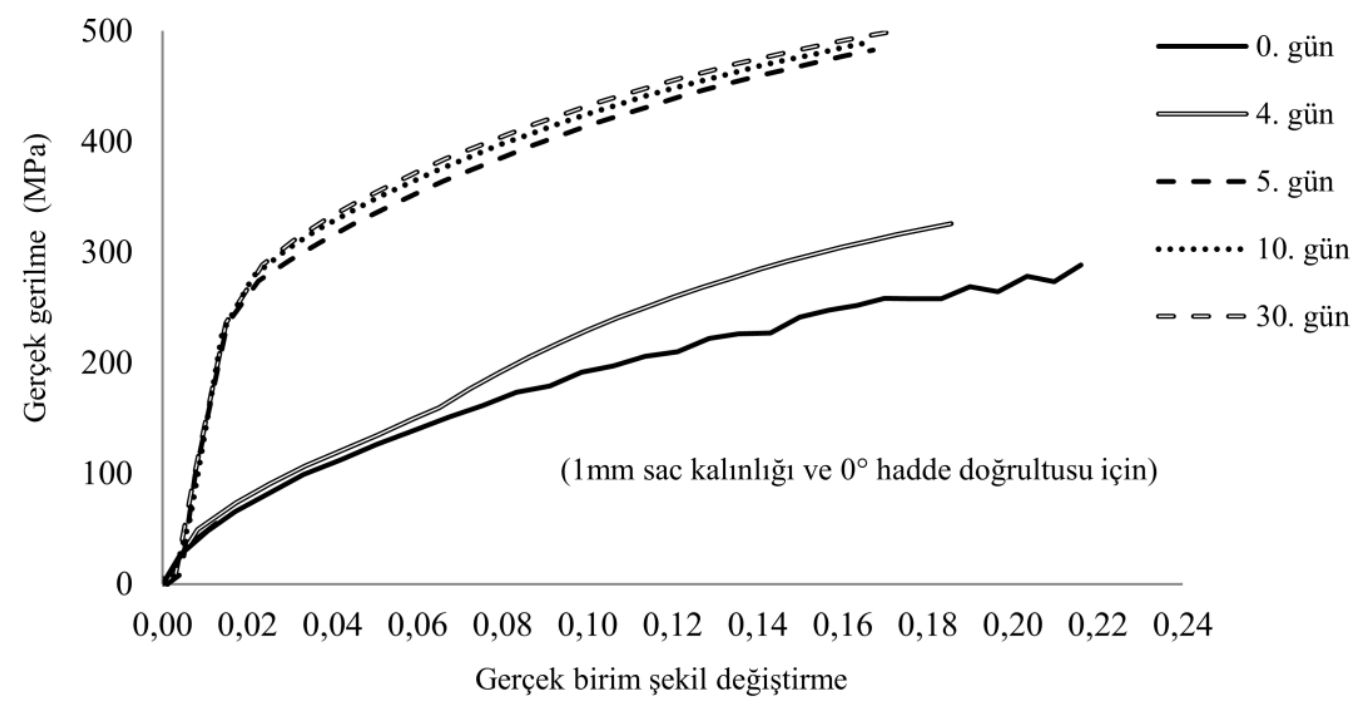

Şekil 10. Al 2024 alaşımının doğal yaşlandırma ile mekanik özelliklerin değişimi

Çizelge 4. Testlerden elde edilen sonuçlar

\begin{tabular}{|c|c|c|c|c|c|c|c|c|}
\hline $\begin{array}{c}\text { Test } \\
\text { no }\end{array}$ & $\begin{array}{c}\text { Akma } \\
\text { mukavemeti } \\
(\mathrm{MPa})\end{array}$ & $\begin{array}{c}\text { Çekme } \\
\text { mukavemeti } \\
(\mathrm{MPa})\end{array}$ & $\begin{array}{c}\text { Toplam } \\
\text { uzama } \\
(\%)\end{array}$ & $\begin{array}{c}\text { EI } \\
(\mathrm{mm})\end{array}$ & $\begin{array}{c}\text { Amaç } \\
\text { fonksiyonu } \\
\text { Akma muk. }\end{array}$ & $\begin{array}{c}\text { Amaç } \\
\text { fonksiyonu } \\
\text { Cekme muk. }\end{array}$ & $\begin{array}{c}\text { Amaç } \\
\text { fonksiyonu } \\
\text { Top. uzama }\end{array}$ & $\begin{array}{c}\text { Amaç } \\
\text { fonksiyonu } \\
\text { EI }\end{array}$ \\
\hline 1 & 252 & 433 & $16,80 \%$ & 22,8 & 48,03 & 52,72 & $-15,49$ & 27,16 \\
\hline 2 & 272 & 445 & $16,38 \%$ & 23,2 & 48,69 & 52,96 & $-15,71$ & 27,31 \\
\hline 3 & 251 & 441 & $15,23 \%$ & 21,6 & 47,99 & 52,90 & $-16,34$ & 26,69 \\
\hline 4 & 302 & 454 & $19,10 \%$ & 26,3 & 49,60 & 53,14 & $-14,38$ & 28,40 \\
\hline 5 & 278 & 468 & $17,20 \%$ & 24,2 & 48,88 & 53,40 & $-15,29$ & 27,68 \\
\hline 6 & 261 & 454 & $16,55 \%$ & 23,5 & 48,33 & 53,15 & $-15,62$ & 27,42 \\
\hline 7 & 260 & 446 & $15,10 \%$ & 23,8 & 48,30 & 52,98 & $-16,42$ & 27,53 \\
\hline 8 & 250 & 433 & $15,72 \%$ & 21,7 & 47,96 & 52,73 & $-16,07$ & 26,73 \\
\hline 9 & 252 & 434 & $16,30 \%$ & 23,5 & 48,03 & 52,75 & $-15,76$ & 27,42 \\
\hline & & & & & 48,42 & 52,97 & $-15,68$ & 27,37 \\
\hline Ortalama & 264 & 445 & $16,49 \%$ & 23 & & & & \\
\hline Standart & 16 & 11 & $1,13 \%$ & 1 & & & & \\
\hline sapma & & & & & & & & \\
\hline
\end{tabular}


Çizelge 5.Toplam uzama için ANOVA çizelgesi

\begin{tabular}{|c|c|c|c|c|c|c|c|c|c|}
\hline \multirow[t]{2}{*}{ No } & \multirow[t]{2}{*}{ Faktör } & \multicolumn{3}{|c|}{$\begin{array}{l}\text { Faktör düzeylerinin } \\
\text { ortalaması } \eta\end{array}$} & \multirow[t]{2}{*}{$\begin{array}{l}\text { Serbestlik } \\
\text { derecesi }\end{array}$} & \multirow[t]{2}{*}{$\begin{array}{l}\text { Karelerin } \\
\text { toplamı }\end{array}$} & \multirow[t]{2}{*}{$\begin{array}{c}\text { Ortalama } \\
\text { kareler }\end{array}$} & \multirow[t]{2}{*}{$\begin{array}{l}\text { Değişim } \\
\text { oranı }\end{array}$} & \multirow[t]{2}{*}{$\begin{array}{l}\text { Katk1 } \\
\text { oranı }\end{array}$} \\
\hline & & 1 & 2 & 3 & & & & & \\
\hline 1 & $\begin{array}{l}\text { A: Çözeltiye alma sıcaklığı } \\
\left({ }^{\circ} \mathrm{C}\right)\end{array}$ & 27,05 & 27,83 & 27,23 & 2 & 1,00 & 0,50 & 0,95 & 47,68 \\
\hline 2 & $\begin{array}{l}\text { B: Suya verme gecikme } \\
\text { süresi (sn) }\end{array}$ & 27,70 & 27,24 & 27,18 & 2 & 0,48 & 0,24 & 0,46 & 22,93 \\
\hline 3 & $\begin{array}{l}\text { C: Çözeltiye alma süresi } \\
\text { (dk) }\end{array}$ & 27,10 & 27,71 & 27,30 & 2 & 0,58 & 0,29 & 0,55 & 27,33 \\
\hline 4 & D: Isınma hızı ( ${ }^{\circ} \mathrm{C} /$ saat $)$ & 27,42 & 27,42 & 27,27 & 2 & 0,04 & 0,02 & 0,04 & 2,06 \\
\hline \multirow{2}{*}{\multicolumn{5}{|c|}{$\begin{array}{l}\text { Toplam } \\
\text { (Hata) }\end{array}$}} & 8 & 2,107 & 0,263 & & \\
\hline & & & & & 4 & 0,527 & 0,132 & & \\
\hline
\end{tabular}

Çizelge 6. Akma mukavemeti için ANOVA çizelgesi

\begin{tabular}{|c|c|c|c|c|c|c|c|c|c|}
\hline No & \multirow[t]{2}{*}{ Faktör } & \multicolumn{3}{|c|}{$\begin{array}{l}\text { Faktör düzeylerinin } \\
\text { ortalaması } \eta\end{array}$} & \multirow[t]{2}{*}{$\begin{array}{l}\text { Serbestlik } \\
\text { derecesi }\end{array}$} & \multirow[t]{2}{*}{$\begin{array}{l}\text { Karelerin } \\
\text { toplamı }\end{array}$} & \multirow[t]{2}{*}{$\begin{array}{c}\text { Ortalama } \\
\text { kareler }\end{array}$} & \multirow{2}{*}{$\begin{array}{c}\begin{array}{c}\text { Değişim } \\
\text { oranı }\end{array} \\
1\end{array}$} & \multirow[t]{2}{*}{$\begin{array}{l}\text { Katk } 1 \\
\text { oranı }\end{array}$} \\
\hline & & 1 & 2 & 3 & & & & & \\
\hline 1 & $\begin{array}{l}\text { A: Çözeltiye alma sıcaklığı } \\
\left({ }^{\circ} \mathrm{C}\right)\end{array}$ & 48,24 & 48,94 & 48,10 & 2 & 1,22 & 0,610 & 1,19 & 50,8 \\
\hline 2 & $\begin{array}{l}\text { B: Suya verme gecikme süresi } \\
\text { (sn) }\end{array}$ & 48,64 & 48,51 & 48,12 & 2 & 0,45 & 0,223 & 0,44 & 18,6 \\
\hline 3 & C: Çözeltiye alma süresi (dk) & 48,11 & 48,77 & 48,39 & 2 & 0,67 & 0,336 & 0,66 & 27,9 \\
\hline 4 & D: Isınma hızı ( ${ }^{\circ} \mathrm{C} /$ saat $)$ & 48,31 & 48,44 & 48,52 & 2 & 0,06 & 0,032 & 0,06 & 2,7 \\
\hline \multirow{2}{*}{\multicolumn{5}{|c|}{$\begin{array}{l}\text { Toplam } \\
\text { (Hata) }\end{array}$}} & 8 & 2,403 & 0,300 & & \\
\hline & & & & & 4 & 0,511 & 0,128 & & \\
\hline
\end{tabular}

Çizelge 7. Toplam uzama için ANOVA çizelgesi

\begin{tabular}{|c|c|c|c|c|c|c|c|c|c|}
\hline \multirow[t]{2}{*}{ No } & \multirow[t]{2}{*}{ Faktör } & \multicolumn{3}{|c|}{$\begin{array}{l}\text { Faktör düzeylerinin } \\
\text { ortalaması } \eta\end{array}$} & \multirow[t]{2}{*}{$\begin{array}{c}\text { Serbestlik } \\
\text { derecesi }\end{array}$} & \multirow[t]{2}{*}{$\begin{array}{l}\text { Karelerin } \\
\text { toplamı }\end{array}$} & \multirow[t]{2}{*}{$\begin{array}{c}\text { Ortalama } \\
\text { kareler }\end{array}$} & \multirow[t]{2}{*}{$\begin{array}{c}\text { Değişim } \\
\text { oranı }\end{array}$} & \multirow[t]{2}{*}{$\begin{array}{l}\text { Katk1 } \\
\text { oranı }\end{array}$} \\
\hline & & 1 & 2 & 3 & & & & & \\
\hline 1 & $\begin{array}{l}\text { A: Çözeltiye alma sıcaklığ } 1 \\
\left({ }^{\circ} \mathrm{C}\right)\end{array}$ & $-15,85$ & $-15,10$ & $-16,08$ & 2 & 1,59 & 0,795 & 1,29 & 52,5 \\
\hline 2 & $\begin{array}{l}\text { B: Suya verme gecikme } \\
\text { süresi (sn) }\end{array}$ & $-15,43$ & $-15,69$ & $-15,91$ & 2 & 0,34 & 0,171 & 0,28 & 11,3 \\
\hline 3 & C: Çözeltiye alma süresi (dk) & $-15,73$ & $-15,28$ & $-16,02$ & 2 & 0,82 & 0,411 & 0,67 & 27,2 \\
\hline 4 & D: Isınma hızı ( $\left({ }^{\circ} \mathrm{C} /\right.$ saat $)$ & $-15,51$ & $-15,92$ & $-15,60$ & 2 & 0,27 & 0,137 & 0,22 & 9,0 \\
\hline \multirow{2}{*}{\multicolumn{5}{|c|}{$\begin{array}{l}\text { Toplam } \\
\text { (Hata) }\end{array}$}} & 8 & 3,027 & 0,378 & & \\
\hline & & & & & 4 & 0,615 & 0,154 & & \\
\hline
\end{tabular}




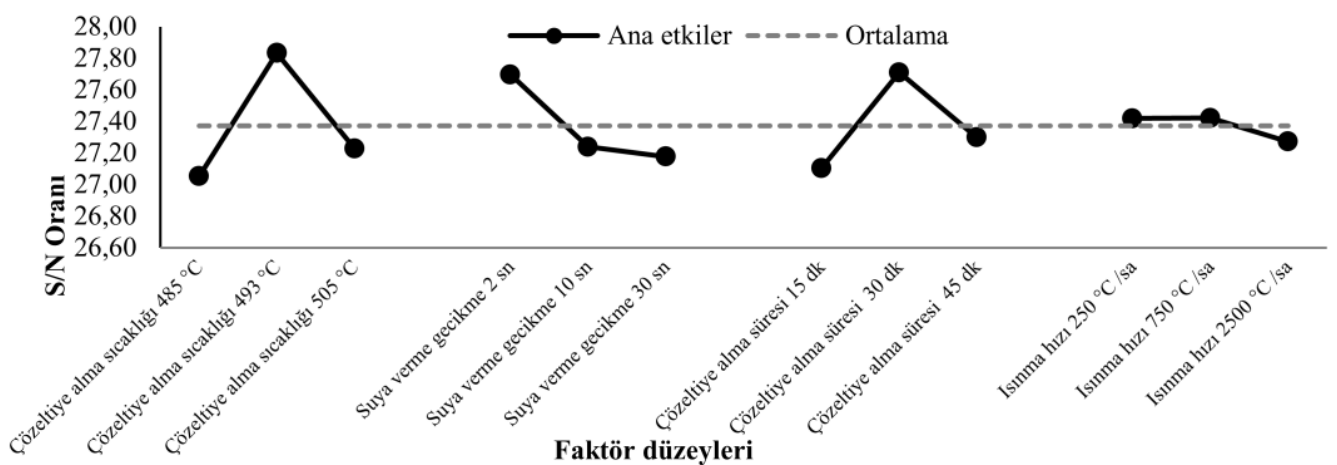

Şekil 11. EI için faktör düzeyleri grafiği

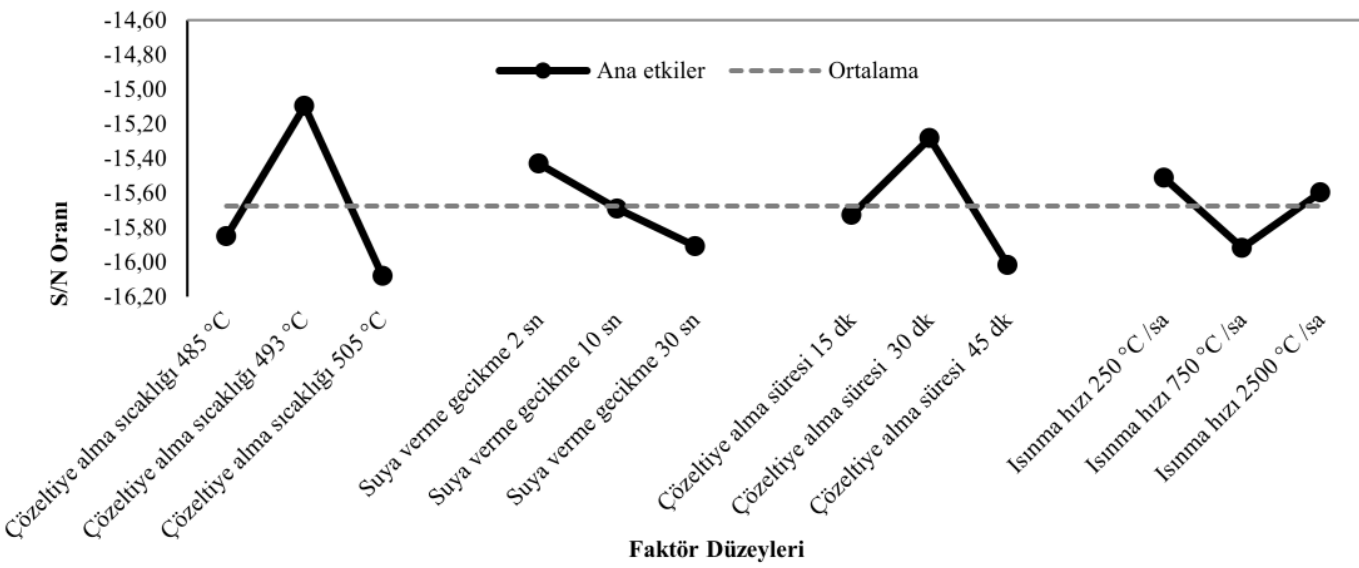

Şekil 12. Akma mukavemeti için faktör düzeyleri grafiği

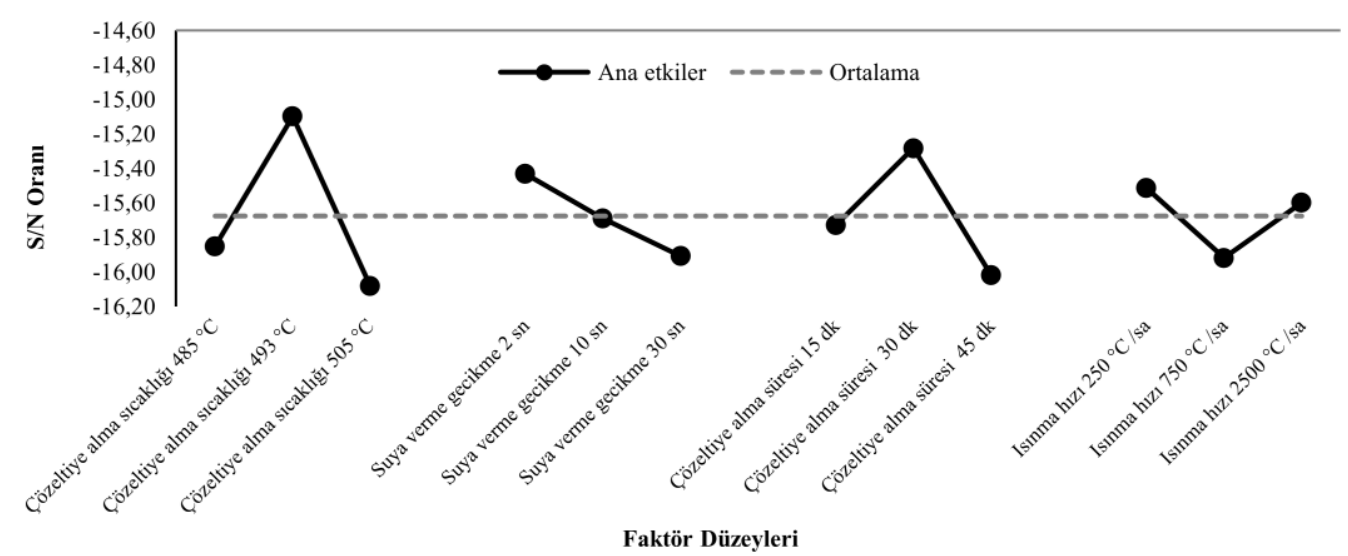

Şekil 13. Toplam uzama için faktör düzeyleri grafiği 
Sadece en etkili parametre olan çözeltiye alma Sıcaklığının ŞSE üzerindeki etkisini görmek için yapılan testler sonucu elde edilen ŞSE'ler Şekil 14'te verilmiştir. Şekilden de görüldüğü gibi, $505^{\circ} \mathrm{C}$ için tüm bölgelerde en düşük seviyede sınır eğri elde edilmiştir ve bu eğri $485^{\circ} \mathrm{C}$ için elde edilen eğri ile birbirine oldukça yakındır. $493^{\circ} \mathrm{C}$ için elde edilen eğri ise bu iki eğriden önemli olabilecek ölçüde yüksek seviyededir. Bu durumda $493^{\circ} \mathrm{C}$ için yapılan çözeltiye alma işleminin Al 2024 malzemenin kalıplama kabiliyeti için optimum değer olduğu belirlenmiştir.

Grid analizi kullanılarak uzatılmış bir numuneden elde edilen örnek bir BŞD dağılımı Şekil 15'te görülmektedir. Yapılan tüm deneylerde, şekilde görüldüğü gibi üniform bir BŞD dağılımı elde edilmiştir.

Grid analizi yöntemiyle çözeltiye alma sıcaklıkları için elde edilen anizotropi değerleri Çizelge 8'de verilmiştir. Çizelgedeki değerler incelendiğinde, $493^{\circ} \mathrm{C}$ sıcaklık için elde edilen normal anizotropi değerinin en yüksek olduğu görülmektedir. $\mathrm{Bu}$ sıcaklığın alt ve üstünde ise malzemenin anizotropi değerlerinin yani incelmeye karşı direncinin azaldığ 1 anlaşılmaktadır. Buradan, $493^{\circ} \mathrm{C}$ çözeltiye alma sıcaklığının optimum değer olduğu anlaşılmaktadır.

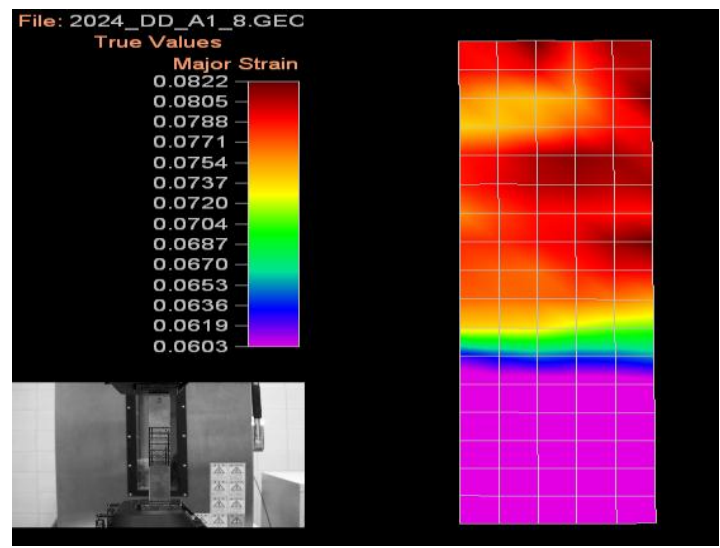

Şekil 15. Tipik bir anizotropi numunesindeki üniform BŞD dağılımı

Elde edilen optimum 1sıl işlem koşullarının daha hassas olarak tespit edilebilmesi için deneysel sonuçların tahmin edileceği bir yapay sinir ağı tabanlı bulanık mantık modeli oluşturulmuştur. Böylece test yapılmayan koşullar için de sonuçlar elde edilmiştir. Elde edilen tahmin sonuçları ve deneysel sonuçların karşılaştırılması Şekil 16'da ve Çizelge 9'da verilmiştir. Ortalama tahmin hataları ise Çizelge 10'da verilmiştir. Yapılan modelleme sonucunda 4 çıkış parametresi tahmin edilmiştir. Bu sonuçların deneysel sonuçlar ile çok yakın olduğu Çizelge 9'dan görülmektedir.

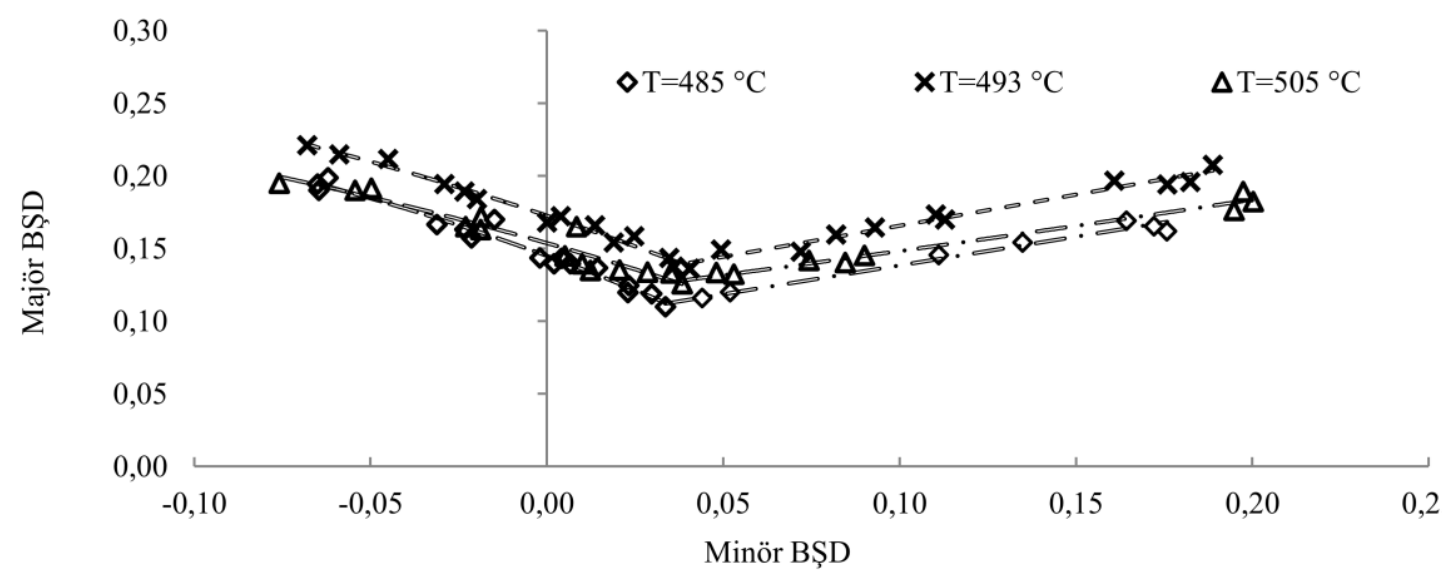

Şekil 14. Çözeltiye alma sıcaklığının ŞSE üzerindeki etkisi 
Çizelge 8. Çözeltiye alma sıcaklığına göre elde edilen anizotropi değerleri (\% 10 uzama için)

\begin{tabular}{|c|c|c|c|}
\hline Çözeltiye alma sıcaklığ $1\left({ }^{\circ} \mathrm{C}\right)$ & Hadde doğrultusu & $\begin{array}{c}\text { Normal } \\
\text { anizotropi }\end{array}$ & $\begin{array}{c}\text { Ortalama } \\
\text { normal } \\
\text { anizotropi }\end{array}$ \\
\hline \multirow{3}{*}{485} & $0^{\circ}$ & 0,66 & \multirow{3}{*}{0,795} \\
\hline & $45^{\circ}$ & 0,85 & \\
\hline & $90^{\circ}$ & 0,82 & \\
\hline \multirow{3}{*}{493} & $0^{\circ}$ & 0,70 & \multirow{3}{*}{0,853} \\
\hline & $45^{\circ}$ & 0,93 & \\
\hline & $90^{\circ}$ & 0,85 & \\
\hline \multirow{3}{*}{505} & $0^{\circ}$ & 0,63 & \multirow{3}{*}{0,758} \\
\hline & $45^{\circ}$ & 0,80 & \\
\hline & $90^{\circ}$ & 0,80 & \\
\hline
\end{tabular}

Çizelge 9. Yapay sinir ağı tabanlı- bulanık mantık modelinin tahmin sonuçları

\begin{tabular}{ccccccccc}
$\begin{array}{c}\text { Test } \\
\text { no }\end{array}$ & $\begin{array}{c}\text { Deneysel } \\
\text { akma } \\
\text { mukavemeti } \\
(\mathrm{MPa})\end{array}$ & $\begin{array}{c}\text { Tahmin } \\
\text { edilen akma } \\
\text { mukavemeti } \\
(\mathrm{MPa})\end{array}$ & $\begin{array}{c}\text { Deneysel } \\
\text { çekme } \\
\text { mukavemeti } \\
(\mathrm{MPa})\end{array}$ & $\begin{array}{c}\text { Tahmin } \\
\text { edilen } \\
\text { çekme } \\
\text { mukavemeti } \\
(\mathrm{MPa})\end{array}$ & $\begin{array}{c}\text { Deneysel } \\
\text { toplam \% } \\
\text { uzama }\end{array}$ & $\begin{array}{c}\text { Tahmin } \\
\text { edilen } \\
\text { toplam } \\
\%\end{array}$ & $\begin{array}{c}\text { Deneysel } \\
\text { Ericksen } \\
\text { İndeksi } \\
(\mathrm{mm})\end{array}$ & $\begin{array}{c}\text { Tahmin } \\
\text { edilen } \\
\text { Ericksen } \\
\text { Indeksi } \\
(\mathrm{mm})\end{array}$ \\
\hline 1 & 252 & 251,564 & 433 & 432,082 & 16,80 & 16,82 & 22,8 & 21,35 \\
\hline 2 & 272 & 272 & 445 & 445 & 16,38 & 16,38 & 23,2 & 23,2 \\
\hline 3 & 251 & 251 & 441 & 441 & 15,23 & 15,23 & 21,6 & 21,6 \\
\hline 4 & 302 & 300,951 & 454 & 456,851 & 19,10 & 19,09 & 26,3 & 25,45 \\
\hline 5 & 278 & 274,377 & 468 & 466,775 & 17,20 & 17,21 & 24,2 & 22,8 \\
\hline 6 & 261 & 257,550 & 454 & 452,985 & 16,55 & 16,54 & 23,5 & 22,4 \\
\hline 7 & 260 & 260 & 446 & 446 & 15,10 & 15,10 & 23,8 & 23,8 \\
\hline 8 & 250 & 249,514 & 433 & 431,862 & 15,72 & 15,74 & 21,7 & 20,6 \\
\hline 9 & 252 & 251,238 & 434 & 432,665 & 16,30 & 16,24 & 23,5 & 22,9 \\
\hline Ort, & 264 & 263,1327 & 445 & 445,0244 & $16,49 \%$ & 16,4833 & 23 & 22,6778 \\
\hline
\end{tabular}

Çizelge 10. Ortalama tahmin hataları

\begin{tabular}{cccc}
\hline Akma Mukavemeti & Çekme Mukavemeti & Toplam \% uzama & Ericksen İndeksi \\
\hline$\% 0,6186$ & $\% 0,1040$ & $\% 0,0295$ & $\% 4,797$ \\
\hline
\end{tabular}




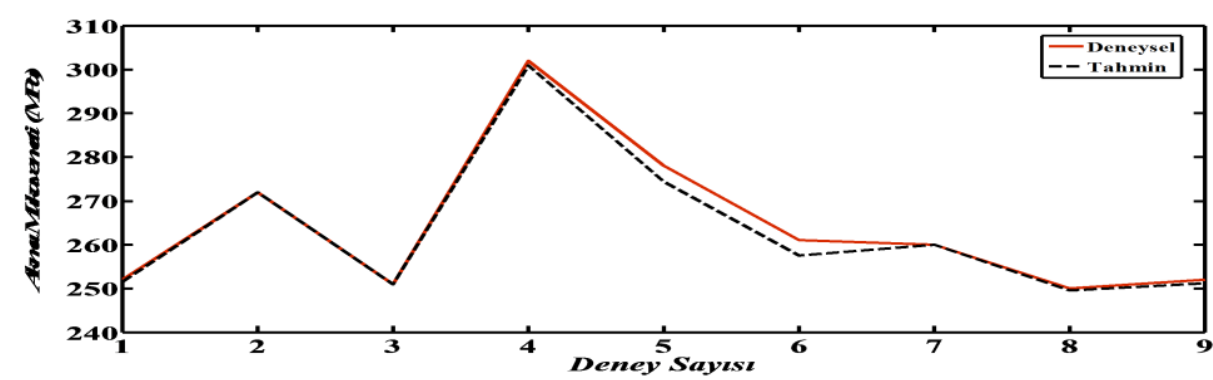

a)

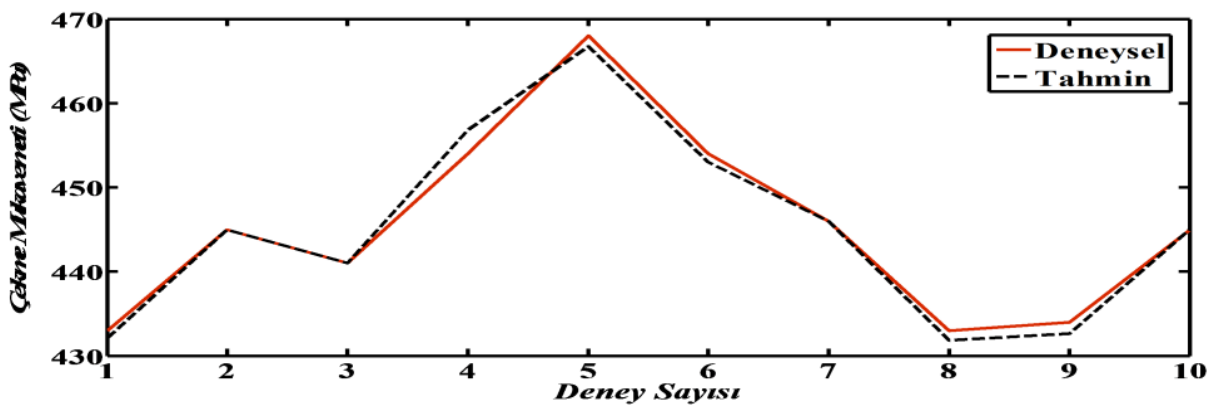

b)



c)

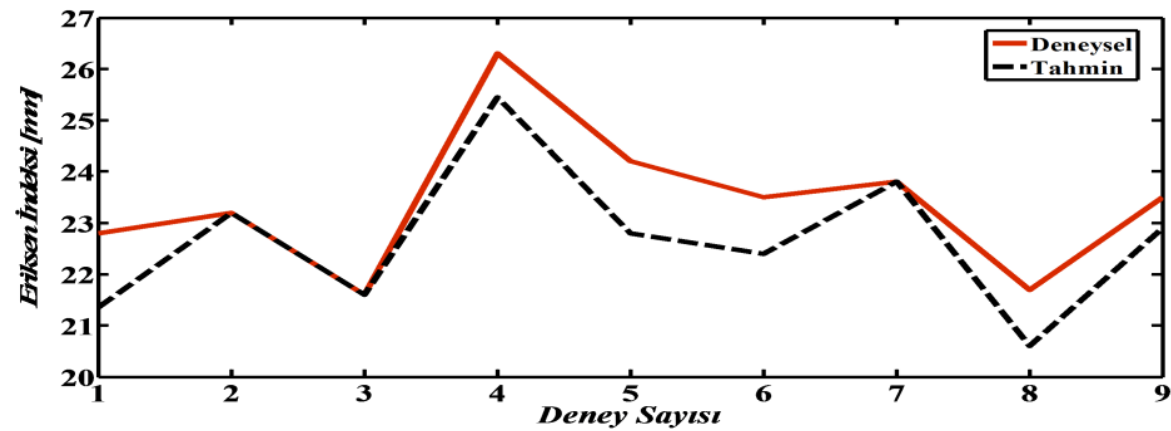

d)

Şekil 16. a) akma, b) çekme, c) toplam \% uzama ve d) EI için tahmin ve deneysel sonuçların karşılaştırılması 
Ortalama tahmin hataları Çizelge 10'da verilmiștir. $\mathrm{Bu}$ sonuçlara göre ortalama tahmin hatası $\% 1,38$ şeklindedir.

Elde edilen optimum isıl işlem koşullarının daha hassas olarak tespit edilebilmesi için deneysel sonuçların tahmin edileceği bir yapay sinir ağ1 tabanlı bulanık mantık modeli oluşturulmuştur. Böylece test yapılmayan koşullar için de sonuçlar elde edilmiştir. Elde edilen tahmin sonuçları ve deneysel sonuçların karşılaştırılması Şekil 16'da ve Çizelge 9'da verilmiştir. Ortalama tahmin hataları ise Çizelge 10 'da verilmiştir. Yapılan modelleme sonucunda 4 çıkış parametresi tahmin edilmiştir. Bu sonuçların deneysel sonuçlar ile çok yakın olduğu Çizelge 9'dan görülmektedir. Ortalama tahmin hataları Çizelge 10'da verilmiştir. $\mathrm{Bu}$ sonuçlara göre ortalama tahmin hatası \%1,38 şeklindedir.

Elde edilen sonuçlara göre, tahmin edilen değerlerin testler sonucunda elde edilenlerle oldukça uyumlu olması, oluşturulan modelin doğruluğunu ortaya koymaktadır. Böylece test yapılmayan koşullar için de malzemeye ait EI, akma ve \% uzama değerleri elde edilebilecektir.

Isıl işlem koşullarının değişmesiyle EI, akma mukavemeti ve toplam \% uzama değerleri sırasıyla $\% 18, \quad \% 15$ ve $\% 20$ oranında değişiklik göstermiştir. $\mathrm{Bu}$ değişimler önemli ölçüde olduğundan, Al 2024 malzemenin 1sıl işlem koşullarının mekanik özellikler ve şekillendirilebilirlik üzerinde önemli bir etkisinin olduğu sonucuna varılmıştır. Sonuç olarak, Al 2024 malzeme için $493^{\circ} \mathrm{C}$ 'de 30 dakika çözeltiye alma ve 2 sn gibi çok kısa bir sürede suya verme koşullarında, EI, akma mukavemeti ve \% uzama değerleri en uygun değerlerin elde edilebileceği anlaşılmıştır. Optimum 1sıl işlem koşullarındaki bir malzemeden elde edilen EI, akma mukavemeti ve $\%$ uzama değerleri sirasıyla $26,6 \mathrm{~mm}, \% 19,1$ ve $302 \mathrm{MPa}$ olarak belirlenmiştir.

\section{SONUÇLAR}

Bu çalışmada, Al 2024 alaşımlı alüminyum sac malzemenin çökelme sertleşmesi işlemi koşullarının mekanik özelliklere ve Ericksen
İndeksine etkisi ANOVA analiz ve Yapay Sinir Ağı Tabanlı Bulanık Mantık yöntemleriyle incelenmiştir. Optimum 1sıl işlem koşulları ANOVA analiz yöntemiyle incelenmiş ve elde edilen deneysel sonuçlara göre deney sisteminin yapay sinir ağı tabanlı bulanık mantık modeli oluşturulmuştur. Ayrıca etkili parametrelerin ŞSE ve anizotropi üzerindeki etkisi de incelenmiştir. Araştırma sonuçlarına göre;

- Al 2024 sac malzemenin çözeltiye alma sıcaklığının malzemenin EI ve mekanik özellikleri üzerinde en etkili parametre olduğu görülmüştür. Çözeltiye alma sıcaklığı için $493^{\circ} \mathrm{C}$ 'nin optimum sicaklık olduğu ve bu sıcaklığın altında ve üzerindeki sıcaklıklar için malzemenin EI, mekanik özellikleri, anizotropi değeri ve ŞSE'sinin önemli ölçüde azaldığı görülmüştür.

- Çözeltiye alma süresi ve suya verme gecikme süresinin, çözeltiye alma sıcaklığından sonra etkili parametreler olduğu ancak bu parametrelerin etkisinin daha az ve birbirlerine yakın oldukları tespit edilmiştir. En yüksek mekanik özellikler ve EI için çözeltiye alma süresinin 30 dakika olduğu görülmüştür.

- Suya verme gecikme süresi için ise en optimum değerin en kısa süre olan 2 sn'de elde edildiği görülmüştür. Suya verme gecikme süresi arttıkça akma, çekme mukavemetleri ve şişme yüksekliğinin azaldığı gözlenmiştir. Al 2024 malzemeden iyi özellikler elde edilebilmesi için çözeltiye alma işleminden sonra mümkün olduğunca çabuk suya verilmesi uygun olacaktır.

- Isınma hızının malzemenin EI ve mekanik özellikleri üzerinde çok az bir etkisinin olduğu görülmüştür.

- Isıl işlem parametreleri değiştirilerek malzemeye ait EI, akma ve toplam \% uzama değerleri sirasiyla \%18, \%15 ve $\% 20$ oranında değiştirilebileceği anlaşılmıştır.

- Malzemenin en iyi şekillendirilebilirliğe ve mukavemete sahip olması için, 1sıl işlem koşulları; $493^{\circ} \mathrm{C}$ çözeltiye alma sıcaklığı, 30 dakika çözeltiye alma süresi ve 2 sn suya verme gecikme süresi olarak tespit edilmiştir.

- Oluşturulan yapay sinir ağı tabanlı bulanık mantık modelinden elde edilen sonuçların deneysel sonuçlarla oldukça uyumlu olması, 
oluşturulan modelin doğruluğunu ortaya koymaktadır. Böylece test yapılmayan koşullar için de malzemeye ait değerler elde edilerek malzemenin 1sıl işlem koşulları hakkında daha detaylı bir analiz yapılabilecektir.

\section{Semboller}

$\begin{array}{ll}\alpha & \text { Katı solüsyon } \\ m_{A} & \text { Parametre düzeyinin etkisi } \\ S / G & \text { Sinyal/Gürültü oranı } \\ \eta & \text { S/G oranı } \\ m & \text { S/G lerin ortalaması } \\ r & \text { Normal anizotropi } \\ \varepsilon_{\mathrm{w}} & \text { Enine birim daralma } \\ \varepsilon_{t} & \text { Kalınlıktaki birim incelme } \\ \varepsilon_{l} & \text { Boydaki birim uzama }\end{array}$

\section{TEŞEKKÜR}

$\mathrm{Bu}$ çalışma Necmettin Erbakan Üniversitesi Bilimsel Araştırma Projeleri Koordinatörlüğü tarafindan desteklenen 131219007 nolu proje kapsamında gerçekleştirilmiştir. Yazarlar alınan destek için BAP birimine teşekkür eder.

\section{KAYNAKLAR}

1. Campbell, FC, 2006. Manufacturing Technology for Aerospace Structural Materials, UK.

2. ASM Handbook, Properties and Selection: Nonferrous Alloys and Special-Purpose Materials, Vol. 2, USA; 1990.

3. George, E.T., MacKenzie D.S., 2003. Handbook of Aluminum, Physical Metallurgy and Processes, Marcel Dekker Inc., New York,

4. US Army Materials and Mechanics Research Center, Military Standardization Handbook, Aluminum and Aluminum Alloys, 1966.

5. Story, JM. et al., 1993. Issues and Trends in Automotive Aluminum Sheet Forming, International Congress and Exposition, Detroit, Michigan, March 1-5.

6. Cantor, B. et al., 2001. Aerospace Materials, IOP Publishing Ltd, U.K.
7. Smith, WF, 1997, Foundation of Material Science and Engineering, 3rd Edition, McGraw Hill.

8. Anonymous, 2002. Engineering Handbook Series for Aircraft Repair General Manual for Structural Repair, Second Edition; NAVWEPS 01-1A-1; T.O. 1-1A-1.

9. Elwin, L.R., 1990. ASM Handbook Volume 2, Properties and Selection: Nonferrous Alloys and Special-Purpose Materials, Introduction to Aluminum and Aluminum Alloys, ASM International, America.

10. Hatipoğlu, H.A., 2007. Experimental and Numerical Investigation of Sheet Metal Hydroforming (Flexforming) Process. Master Sci. Thesis, Middle East Technical University, Ankara.

11. Smith, W.F., 1997. Foundation of Material Science and Engineering, 3rd Edition, McGraw Hill.

12. Totten, G.E., MacKenzie, D.S., 2003. Handbook of Aluminum Volume 7 Physical Metallurgy and Processes, Marcel Dekker, New York.

13. Ortiz, D. et al., 2007. Effect of Cold Work on the Tensile Properties of 6061, 2024 and, 7075 Al Alloys, Journal of Materials Engineering and Performance, 16 (5), 515-520.

14. Vargel, C., 2004. Corrosion of Aluminum, Elsevier Ltd., U.K.

15. Lewison, D.J., 1999. An Assessment of Different Experimental Methods for Determination of Forming Limits, Master's Thesis, Rensselaer Polytechnic Institute.

16. Raghavan, K.S., 1995. A Simple Technique to Generate In-Plane Forming Limit Curves and Selected Applications, Metallurgical and Materials Transactions A, 26A, 2075-2084.

17. Öztürk, F., Lee, D., 2005. Experimental and Numerical Analysis of Out-of-plane Formability Test, Journal of Materials Processing Technology, 170, 247-253.

18. Dilmec, M., Halkaci, H.S., Öztürk, F., Türköz, M., 2013. Detailed Investigation of Forming Limit Determination Standards for Aluminum Alloys, Journal of Testing and Evaluation 41(1): 10-21.

19. Dilmeç, M., 2012. 2024-T4 Alüminyum Sacların Şekillendirme Sınır Eğrilerinin 
Kalınlığa Göre Değişimi, Doktora Tezi, Selçuk Üniversitesi Fen Bilimleri Enstitüsü, Konya.

20. Dilmeç, M., Arıkan H., 2014. Effect of Solution Heat Treatment Conditions on the Mechanical Properties and Formability for AA 2024 Alloy, Applied Mechanics and Materials 686: 3-9. 